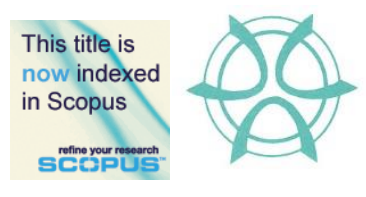

PLANNING MALAYSIA:

Journal of the Malaysian Institute of Planners

VOLUME 16 ISSUE 2 (2018), Page 62 - 72

\title{
HERITAGE BUILDING PRESERVATION THROUGH BUILDING INFORMATION MODELLING: REVIVING CULTURAL VALUES THROUGH LEVEL OF DEVELOPMENT EXPLORATION
}

\author{
Maisarah Ali ${ }^{1}$, Kamsiah Mohd Ismail ${ }^{2}$, Khairusy Syakirin Has-Yun \\ Hashim $^{3}$, Saifulnizam Suhaimi ${ }^{4}$, \& Muhammad Hadi Mustafa ${ }^{5}$ \\ ${ }^{1}$ Kulliyyah of Engineering \\ INTERNATIONAL ISLAMIC UNIVERSITY MALAYSIA
}

${ }^{2,3,4,5}$ Kulliyyah of Architecture and Environmental Design

INTERNATIONAL ISLAMIC UNIVERSITY MALAYSIA

\begin{abstract}
Despite the rich and diverse heritage buildings in Malaysia, they suffer from many problems and threats. Many heritage buildings are deteriorating, and this threatens the country's cultural values. The deterioration of built heritage is a result of the poor inheritance of its related documentation and need to be addressed. Thus, this study brought forward the concept of preservation using Building Information Modelling (BIM). Exploring the potential of BIM as a preservation tool in reviving local cultural values might help to balance the problem of poor inheritance or inconsistency in managing historic and documentation maintenance. The aim of this paper is to study the relationship between levels of development (LOD) and usage of BIM in heritage building preservation. This study employs exploratory research using content analysis. The result of the study found that the availability of as-built details (LOD 500) of the building would be the crucial dataset needed for BIM to function in heritage building as H-BIM. This paper suggests on techniques available for constructing Level of Development (LOD) needed for H-BIM.
\end{abstract}

Keywords: BIM, preservation, heritage building information modelling, LOD 
PLANNING MALAYSIA

Journal of the Malaysia Institute of Planners (2018)

\section{INTRODUCTION}

Stewardship of the built environment balances the needs of contemporary society and their impact on the built environment with its ultimate effects on the natural environment. Merging historic preservation and emerging technologies can create innumerable opportunities for reuse of the built environment, which fosters a more sustainable environment. Moreover, projects are getting more complex, and buildings are more difficult to maintain. As technology grows, there are attempts to attend this matter. In architecture, engineering and construction (AEC) industry, the significance of reliable information is paramountly important (Arayici, Egbu, \& Coates, 2012). This is because the industry compractices multiand-interdisciplinary work in achieving project success.

Historic resources are meant to be preserved for the enjoyment and the education of future generations. However, the management of records and documentation is difficult to be kept effectively (Arayici et al., 2017; Antonopoulou, 2017; Khodeir, Aly, \& Tarek, 2016). Moreover, poor inheritance or inconsistently managed historic and documentation maintenance has plagues many industry players, such as preservationists. No matter what causes behind the records management issues, the problems still exist and prevalent (Del Giudice \& Osello, 2013; Murphy, 2012). Inadequate records complicate and hinder preservation efforts. Time and money are often lost in search of information that previously existed but has been lost or misplaced due to unmaintained records. Such situations result in the waste of valuable resources that could be better deployed to sustain or improve a historic resource for heritage buildings which have decades of significant history and useful for a nation's development (Arayici et al., 2012; Murphy, McGovern, \& Pavia, 2013; Harun, 2011). Realizing this space for improvement within the industry, technology development has brought BIM as a platform to be considered for the betterment of the industry's practice.

Building Information Modelling (BIM) is a process of digitally illustrating all the elements that composed a building (Eastman, 2009). BIM uses software which can translate the drawings into a 3-Dimensional model. In other words, the BIM process involves the assembly of 'intelligent' objects (building components and spaces) into a virtual representation of a building or facility. These consist of geometry in 2D and/or 3D integrated and associated (nongeometric) information (Arayici et al., 2012; Khodeir et al., 2016; Eastman, 2009). Therefore by using BIM, it is able to gather different threads of information related to building and construction process into a single operating environment. Fundamentally, as the information grows to nearing project completion, the level of development increases as well (Eastman, 2009).

In contrast to new building development, heritage buildings have existed for a long time where information pertaining to its design, specification, and construction are segmented in nature. The diaspora of heritage building ranges 
Maisarah Ali, Kamsiah Mohd Ismail, Khairusy Syakirin, Saifulnizam, \& Muhammad Hadi

Heritage Building Preservation Through Building Information Modelling: Reviving Cultural Values Through Level of

Development Exploration

from government buildings down to individual house owner. The risk of having an incomplete documentation and level of details to assist with their building preservation is much greater towards the individual owner. Segmentation of information, incomplete details and poor records keeping are some of the factors that affect the pursuit of preserving one cultural values in a building. The potential of BIM as a tool in overcoming this situation is observed of serving its own potential. However with an existing form and quality of information, the main question triggering this research is how does the level of development work in BIM environment for preservation purposes? Therefore drawing from this fundamental question, this paper aims to study the relationship between levels of developments (LOD) and usage of BIM in heritage building preservation.

\section{BUILDING INFORMATION MODELLING (BIM)}

BIM objects are parametric, with defined rules and may automatically adjust to changes in which the information is integrated into the model in a structured way. By adding the relevant pieces of information corresponding to BIM objects (Antonopoulou, 2017; Abbasnejad \& Moud, 2013), its model constitutes to a digital information resource for the built asset.

BIM supports the management of the information collected, modeled, used and shared by the different disciplines involved in the whole lifecycle process of the building. It improves availability and accessibility of all the information related to the structure, making it easier to interpret its nature, monitor its changes and document each activity related to it (Khodeir et al., 2016; Harun, 2011). Any changes and decisions made rely on the knowledge accurately formalized in the proposed model, supporting the identification of any situations, the scheduling of activities and the planning of routine management and maintenance (Khodeir et al., 2016; Hamid, \& Embi, 2016; Volk, Stengel, \& Schultmann, 2014).

\section{Features and benefits of BIM}

BIM is an intelligent model-based process to efficiently plan, design, construct, and manage buildings and infrastructure. Most BIM software includes the following functions, which can be particularly useful in many projects (Antonopoulou, 2017; Khodeir et al., 2016; Abbasnejad \& Mohd, 2013):

- as multiple design options, such as an analysis of proposed activities,

- as a clash detection, for highly accurate spatial coordination of new design with existing design

- Integration of various datasets, such as historic information, photographs, and drawings.

- integration of intangible information, such as significance and heritage values that are associated with specific components or spaces; 
- interoperability, for data sharing and reuse across a multi-disciplinary team; - Interfacing with other enterprise systems, such as GIS, websites, CMMS, and some databases system.

These benefits of BIM can lead to design consistency and visualization, cost estimations, clash detection, and improved stakeholder collaboration (Eastman, 2009; Hamid \& Embi, 2016; Eastman, 1992). Valuable data inventory (dataset) such as documentation of maintenance details, product's condition, information monitoring, and space management can be developed quickly using this platform (Antonopoulou, 2017).

BIM software makes up about one-half of the components in the whole process. Therefore, the adoption BIM technology requires efficient, and less costly way of working (Antonopoulou, 2017; Azhar, Khalfan, \& Maqsood, 2015). All the data needs to be formatted in the right way and available at the right time is not acting as barriers to its full adoption. The challenges are the unavailability of sufficient experts within the country, relevant equipment for practicing are scarce, limited availability of trainers, and financial-related challenges (Del Giudice \& Osello, 2013; Harun, 2011; Zahrizan, Ali, Haron, Marshall-Ponting, \& Hamid, 2013; Abbasnejad \& Moud 2013).

These difficulties, however, should not prevent, or even discourage construction players from taking advantage on this technology advancement in different ways.

\section{HERITAGE BUILDING PRESERVATION IN MALAYSIA}

In Malaysia, there are many great values and diverse heritage buildings available. According to the statistic by Jabatan Warisan Negara (2013), under Section 76, there were about 176 cultural heritage that have been listed as National Heritage in Malaysia. Although some of them have been properly conserved, many of these buildings still suffer from deficiencies, being abandoned and devalued without proper maintenance except minor repair works (Harun, 2011; Ali, Ibrahim, Haji, Yunus, \& Yahya, 2016). In short, it suffers from many problems and threats.

The distribution of historical buildings in Malaysia shows more than 20,000 buildings are considered historical and worthy of conservation. Example of historic buildings in Malaysia are mosques, residential, schools, railway stations, hotels, churches, palaces, clock towers, prisons, government offices, institutions and commercials, forts and monuments (Harun, 2011).

Among the problems that exist are the Malay realm suffers from rapid destruction of valuable old traditional Malay villas and palaces that reflects Malaysian history and identity. Besides intended demolition of buildings, some other buildings suffer from partial collapsing due to their deteriorated condition. Low maintenance, mismanagement, and weakness in enforcing laws and policies are some of the deterioration reasons (Murphy et al., 2013). 
Maisarah Ali, Kamsiah Mohd Ismail, Khairusy Syakirin, Saifulnizam, \& Muhammad Hadi

Heritage Building Preservation Through Building Information Modelling: Reviving Cultural Values Through Level of Development Exploration

The effects of time and weather conditions with the low maintenance can constitute to make the problem worse (Harun, 2011).

Experts have acknowledged that work involving heritage building is not the same as any other construction work (Ali et al., 2016). In-depth knowledge and expertise on building material and structures that cause building defects are required. This knowledge is essential to ensure that the authenticity of the building structure and the fabric is preserved while protecting the significance of the building's heritage values. This is utmost important in the process to learn about the condition of the building before any work is carried out.

BIM application on heritage buildings can provide a modeling environment which will be able to improve information management. Information management such as to ensure unambiguity, consistency, coordination, and coherence of all the knowledge are needed to fully understand the structure (Murphy, 2012). Thus, the 3-D modeling of the building in BIM platform with reliable as-built dataset will ensure this (Antonopoulou, 2017; Murphy, 2012).

Unlike the new-build construction sector, where BIM has been widely applied for a number of years at an international level (Volk et al., 2014), it is analyzed from the study that BIM for heritage assets is a new field of research in terms of adoption by heritage professionals (Antonopoulou, 2017). Therefore, this area of study is known as Heritage Building Information Modeling (HBIM) will be highlighted in this paper.

\section{HERITAGE BUILDING INFORMATION MODELLING (HBIM)}

HBIM can be described as a novel system for automatically producing both visualization models and preservation of documents, for example for the recording of historic structures and their environments (Antonopoulou, 2017; Murphy et al., 2013). HBIM also avails in developing details such as the object's surface in its methods of construction by utilizing images to understand texture, massing, and form. Thus BIM can be considered as a dataset of information about the disciplines (Giudice et al., 2013; Abbasnejad \& Moud, 2013; hamid \& Embi, 2016). Other authors used the historic data that enable the development of the details about the object's surface concerning on its methods of construction and material finishing (Antonopoulou, 2017; Khodeir et al., 2016). Thus, HBIM can also be defined as a semantic-aware database of historical buildings, in which the geometric model is connected to descriptive multi-source information (Murphy, 2012; Long, Fleming, \& Brackney, 2011; Tang, Huber, Akinci, Lipman, \& Lytle, 2010).

The first step in the HBIM structuring workflow is the modelling of shapes. The next step is the semantic modelling such as recognition and categorization of objects. The final step is the modelling of relationships between the objects (Murphy et al., 2013; Tang et al., 2010). One area of interest in HBIM 
is the availability of effective tools for the acquisition of suitable and accurate information for the work (Tang et al., 2010). Historical or heritage buildings are usually examples of objects with non-regular and complex geometry, unlike modern constructions which commonly have regular geometry. This has made the work for these buildings more challenging (Tang et al., 2010; Garagnani \& Manferdini, 2013). Moreover, the manual generation of 3D models connected to as-built HBIM is complex and time-consuming. Nevertheless, other information such as analysis and monitoring over time (Tang et al., 2010) concerning historic construction techniques and architectural details can also be inserted as an input.

HBIM can create a database to capture information that will be beneficial (Antonopoulou, 2017; Giudice, 2013; Murphy et al., 2013; Eastman, 2009). The database can become the foundation for building decision-making tools that are capable of measuring cost reductions, cost avoidances and values added (Long et al., 2011; Garagnani, 2013). Therefore the digital collaboration and efficient information management technology of HBIM can also allow active stakeholders involvement.

HBIM allows for improvement in spatial coordination (Volk et al., 2014) and assessment of design options under various scenarios. This is significant in the case of historic assets, where any change in the historic fabric must be carefully considered and justified. It can also provide a review of the building's exterior and interior (Volk et al., 2014). More importantly, it facilitates the availability to survey renovations and changes.

The purpose of developing these preservation documentation require the highest level of accuracy especially in the specification of the detail (Long et al., 2011; Worell, 2015), such as HBIM which used historic data to recreate the past or to restore historic artifacts and buildings (Abbasnejad \& Moud, 2013; Eastman, 1992). HBIM focuses on the emergence of architectural pattern books to define architectural rules and detail. Besides the presentation of a narrative, HBIM can illustrate the evolution and form of classical architecture for computer-based modelling (Murphy, 2012).

\section{LEVEL OF DEVELOPMENT (LOD)}

The level of maturity in HBIM approach is described as the Level of Development (LOD) which endeavors to address that model elements develop at different rates during the design process (NATSPEC, 2013). LOD defines the extent to which model elements have been developed, from conception in the mind of the designer through to their construction and operation (NATSPEC, 2013).

In a project management, LOD acts as a tool to serve the following purposes (Apollonio, Gaiani, \& Sun, 2012; NATSPEC, 2013):

- As a standard reference for project players planning model development 
Maisarah Ali, Kamsiah Mohd Ismail, Khairusy Syakirin, Saifulnizam, \& Muhammad Hadi

Heritage Building Preservation Through Building Information Modelling: Reviving Cultural Values Through Level of

Development Exploration

- For recording the model deliverables

- For planning and coordinating project resources.

- For communicating project requirements to team members and organizing their workflow

- For monitoring progress against the project program

LOD provides visual clues about the relative development and details of model elements such as the dimension and quantities. Elements of identical appearance of various information include manufacturer, model number, serial number of the installed unit, commissioning and maintenance history (Khodeir et al., 2016). Thus, LOD is a measure of reliability applies to many forms of information. The intention of LOD is to provide clarity and certainty about the expectation of everyone involved in a model's development (Long et al., 2011), so that stakeholders can orchestrate their work with confidence (Antonopoulou, 2017; Zahrizan et al., 2013; Tang et al., 2010). As an industry standard, it avails communication and coordination of all project players (NATSPEC, 2013).

Table 1: LOD for BIM Model Element

\begin{tabular}{llll}
\hline LOD & Standard of Detailing & $\begin{array}{l}\text { Graphical } \\
\text { Representation }\end{array}$ & $\begin{array}{l}\text { Quantity, Size, Shape, } \\
\text { Location and Orientation }\end{array}$ \\
\hline 100 & Conceptual & Symbol & Derived from other model \\
200 & Approximate geometry & Generic & Approximate \\
300 & Precise geometry & Generic & Accurate \\
400 & Fabrication & Specific & Approximate \\
500 & As-Built & Verified & Accurate \\
\hline \multicolumn{4}{r}{ *Non-graphic information may also be attached to the model of Element }
\end{tabular}

In table 1, LOD describes as the level of completeness and the steps through which a model can logically progress from the lowest level of conceptual (LOD 100), approximation (LOD 200-400) to the highest level of representational precision which is as-built drawing (LOD 500). Models detailed to this level (LOD 500) have actual dimensions for use similar to as-built drawings. The model can be used by asset and facilities managers for orchestrating and recording maintenance, alterations, and additament of functions, elements and systems of the building (Antonopoulou, 2017; Khodeir et al., 2016; Abbasnejad \& Moud, 2013). It is an ideal platform for maintaining building information for life cycle analysis and costing.

LOD speaks to the degree to which data around a component can be depended on for decision-making purposes at a specific point in time (Volk et al., 2014). This is the most critical idea with regards to collective working plans among consultants and stakeholders, for preservation work. 
Unlike the new-build construction sector, where LOD is applied accordingly to project progress; heritage building is already existing building. Thus, in order to gain accurate data about the heritage buildings; preservationist need to work on getting the LOD 500 (Murphy et al., 2013; Tang et al., 2010; Garagnani \& Manferdini, 2013; Worrel, 2015; NATSPEC, 2013).

\section{LOD 500 AND METHODS OF GETTING THE DETAILS}

LOD 500 consists of accurate shape, form, quantity, size, location, orientation, description and dimensions of the building (Worrel, 2015; Apollonio et al., 2012; NATSPEC, 2013). In practice, LOD is sometimes interpreted as Level of Detail rather than Level of Development. However, there are important dissimilarities such as Level of Detail which is essentially how much detail is included in the model element. The Level of Development is the degree to which the element's geometry and attached information have been thought through. In this instant, the degree to which project team members may rely on the information when using the model. Thus, the Level of Detail can be thought of as an input to the element, while the Level of Development is reliable output.

For modelling purpose in developing the shape, form, and dimensions, the data and information from As-Built Drawings and other technology such as Terrestrial Laser Scanning (TLS) might be one of the possible techniques available nowadays (Worrel, 2015). These two methods are identified for its reliability of information and accuracy (Antonopoulou, 2017; Harun, 2011; Garagnani \& Manferdini, 2013).

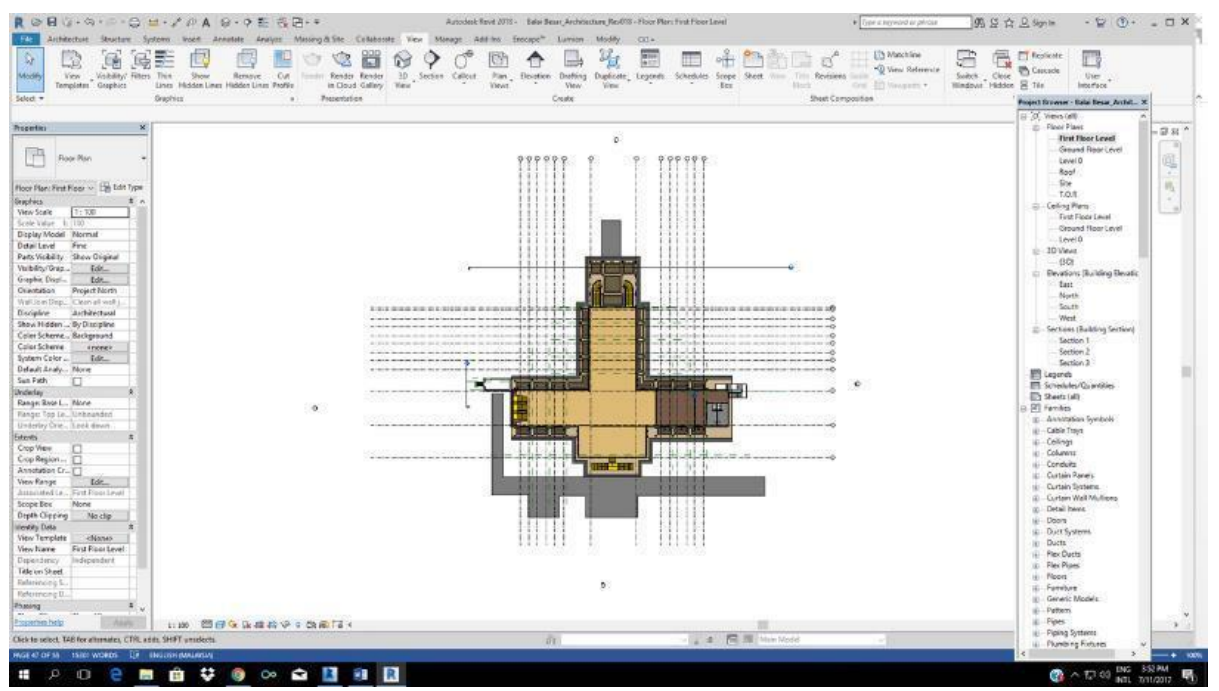

Figure 1: Extracting data and information from as-built drawings for BIM model with LOD 500 
Maisarah Ali, Kamsiah Mohd Ismail, Khairusy Syakirin, Saifulnizam, \& Muhammad Hadi

Heritage Building Preservation Through Building Information Modelling: Reviving Cultural Values Through Level of

Development Exploration

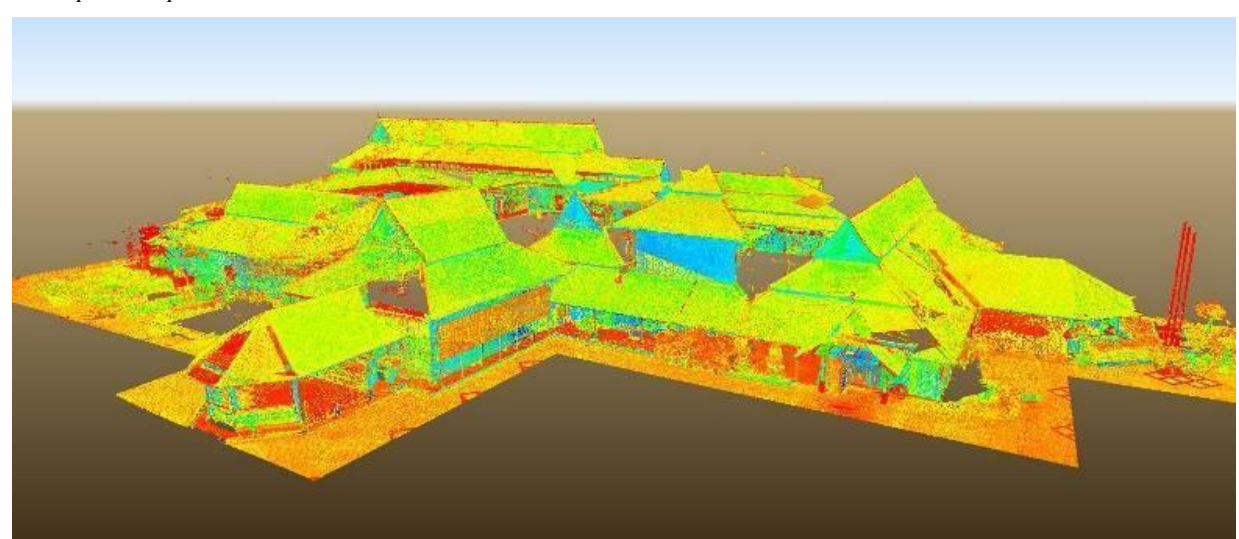

Figure 2: Extracting data and information from terrestrial laser scanning for BIM model with LOD 500

These two techniques guaranteed the standard of detailing is similar to as-built building. The accuracy of the details from techniques such as TLS is verified accurate by these authors (Antonopoulou, 2017; Murphy, 2012; Tang et al., 2010). Both techniques have their own benefits and disadvantages. However, this paper shall not cover on the differences because it requires comparison methodology which deserves a special discussion on that.

For HBIM, the details needed for LOD 500 will focus on the building's component form, design, size or dimension, materials and name (NATSPEC, 2013). However, additional information such as manufacturer's details, orientation, description, cost and other relevant parameters must be inserted if needed. For this study, LOD 500 showed accurate and reliable information to which project team members can rely upon model.

\section{CONCLUSION}

Those in the preservation field know that without adequate historic and maintenance documentation, it is hard to make appropriate decisions for a historic resource. The exploration on how HBIM can be beneficial in heritage buildings preservation effort shows that it can offer positive growth for the sector in Malaysia. The potential benefits of using HBIM in the industry such as preservation seem to be very significant. By knowing techniques on producing LOD 500 for preservation purpose, it will be useful for heritage buildings' interpretation, presentation and simulation applications (Antonopoulou, 2017; Zahrizan et al., 2013; Eastman, 2009). It is recommended that upon completion of this information, the framework on the use of three-dimensional interface for tracking, storing historic information and managing preservation databases should be further discussed. 


\section{ACKNOWLEDGEMENT}

This research was supported by a grant (TRGS16-03-003-0003) from Ministry of Higher Education Malaysia (MOHE). This research is also supported by Kulliyyah of Architecture and Environmental Design (KAED) and Kulliyyah of Engineering of International Islamic University Malaysia.

\section{REFERENCES}

Abbasnejad, B., \& Moud, H. I. (2013). BIM and basic challenges associated with its definitions, interpretations, and expectations. International Journal of Engineering Research and Application, 3(2), 287-294.

Ali, M., Ibrahim, N., Haji, R., Yunus, M., \& Yahya, M. R. (2016). Exploring methods of quantity measurement for heritage conservation works. Advanced Science Letters, 23(7), 6277-6280.

Antonopoulou, S. B. (2017). BIM for heritage: Developing a historic building information model. S.1.: Historic England.

Apollonio, F. I., Gaiani, M., \& Sun, Z. (2012). BIM-based modeling and data enrichment of classical architectural buildings. Scientific Research and Information Technology, 2(2), 41-62.

Arayici, Y., Egbu, C., \& Coates, P. (2012). Building information modeling (BIM) implementation and remote construction projects: Issues, challenges, and critiques. Electronic Journal of Information Technology in Construction, 17, 7592.

Azhar, S., Khalfan, M., \& Maqsood, $\quad$ T. (2015). Building information modelling (BIM): now and beyond. Construction Economics and Building, 12(4), 15-28.

Del Giudice, M., \& Osello, A. (2013, September). BIM for Cultural Heritage. XXIV International CIPA Symposium. September 2-6, 2013, Strasbourg, France.

Eastman, C. (2009). Building Information Modeling What is BIM?

Eastman, C. M. (1992). Modeling of buildings: Evolution and concepts. Automation in Construction, 1(2), 99-109. Hamid, A. B. A., \& Embi, M. R. (2016). Review on Application of Building Information Modelling in Interior Design Industry. MATEC Web Conference, 663, 4-8.

Garagnani, S., \& Manferdini, A. M. (2013). Parametric Accuracy: Building Information Modeling Process Applied To the Cultural Heritage Preservation, $\mathrm{Xl}$ (February), 25-26.

Harun, S. N. (2011). Heritage Building Conservation in Malaysia: Experience and Challenges. Procedia Engineering. 20. 41-53.

Khodeir, L. M., Aly, D., \& Tarek, S. (2016). Integrating HBIM (Heritage Building Information Modeling) tools in the application of sustainable retrofitting of heritage buildings in Egypt. Procedia Environmental Sciences, 34, 258-270.

Long, N., Fleming, K., \& Brackney, L. (2011). An object-oriented database for managing building modeling components and metadata. Proceedings of Building 
Maisarah Ali, Kamsiah Mohd Ismail, Khairusy Syakirin, Saifulnizam, \& Muhammad Hadi

Heritage Building Preservation Through Building Information Modelling: Reviving Cultural Values Through Level of

Development Exploration

Simulation 2011, 2356-2362. Retrieved from

http://www.nrel.gov/docs/fy12osti/51835.pdf

Murphy, M., McGovern, E., \& Pavia, S. (2013) Historic building information modelling - Adding intelligence to laser and image-based surveys of European classical architecture. ISPRS Journal of Photogrammetry and Remote Sensing, 76, 89102 ,

Murphy, M. (2012). Historic building information modelling (HBIM): For recording and documenting classical architecture in Dublin 1700 to 1830. Dublin: Trinity College.

NATSPEC. (2013). BIM and LOD building information modelling and level of development. NATSPEC BIM Paper, (November), 20. Retrieved from https://bim.natspec.org/images/NATSPEC_Documents/NATSPEC_

Tang, P., Huber, D., Akinci, B., Lipman, R., \& Lytle, A. (2010) Automatic reconstruction of as-built building information models from laser-scanned point clouds: A review of related techniques. Automation in Construction, 19(7), 829-843.

Volk, R., Stengel, J., \& Schultmann, F. (2014) Building information models (BIM) for existing buildings - Literature review and future needs. Automation in Construction, 38, 109-127.

Worrell, L. L. (2015). Building information modeling (BIM): The untapped potential for preservation documentation and management (Master thesis). Clemson Unversity, South Carolina, USA.

Zahrizan, Z., Ali, N. M., Haron, A. T., Marshall-Ponting, A., \& Hamid, Z. A. (2013) Exploring the barriers and driving factors in implementing building information modelling (BIM) in the Malaysian construction industry: A preliminary study. The Institute of Engineers, Malaysia, 75(1), 1-10. 